\title{
Millets: Promising Crops for Climate-Smart Agriculture
}

\author{
Biswajit Lenka $^{1 *}$, G. U. Kulkarni ${ }^{1}$, Ankit Moharana ${ }^{2}$, Aditya Pratap Singh ${ }^{3}$, \\ Gouri Shankar Pradhan ${ }^{4}$ and Lakesh Muduli ${ }^{5}$
}

\author{
${ }^{1}$ Department of Genetics and Plant Breeding, Junagadh Agricultural University, \\ Junagadh, Gujarat, India \\ ${ }^{2}$ Department of Seed Science and Technology, ${ }^{5}$ Department of Plant Breeding and Genetics, \\ Odisha University of Agriculture and Technology, Bhubaneswar, Odisha, India \\ ${ }^{3}$ Department of Genetics and Plant Breeding, Bidhan Chandra Krishi Viswavidyalaya, \\ Mohanpur, West Bengal, India \\ ${ }^{4}$ Department of Agronomy, Institute of Agricultural Sciences, Banaras Hindu University, \\ Varanasi, Uttar Pradesh, India \\ *Corresponding author
}

\section{A B S T R A C T}

\section{Keywords}

Nutri-cereals, Climate-resilient, Evading, Photosynthesis, QTL mapping, GCA, SCA, Marker assisted back crossing, Gene pyramiding, Genetic engineering

\section{Article Info}

Accepted: 07 October 2020 Available Online: 10 November 2020
Millets belong to the group of $\mathrm{C}_{4}$ grasses, which incorporate agronomically important crops such as sorghum and maize, bioenergy crops including sugarcane and miscanthus, and nutricereals such as millets. Millets are considered as nutri-cereals because they are plentiful in carbohydrates, dietary fibers, proteins, fat and minerals like iron and calcium. These nutricereals are well known for their climate-resilient feature including adaptation to a wide range of ecological conditions, less water demand and less dependence on synthetic fertilizers. Millets possess several morpho-physiological, molecular and biochemical traits confer better tolerance to changing climate. Short life-cycle (seed to seed) in millet helps in escaping from stress. Traits responsible for evading stress conditions include short stature, small leaf area, thickened cell wall and capability to form dense root system. In the $\mathrm{C}_{4}$ framework, $\mathrm{CO}_{2}$ is concentrated around the enzyme ribulose-1,5-bisphosphate carboxylase oxygenase (RuBISCO) suppressing ribulose-1,5-bisphosphate $(\mathrm{RuBP})$ oxygenation and photorespiration. Since RuBISCO of $\mathrm{C}_{4}$ plants works at elevated $\mathrm{CO}_{2}$ levels, millets have improved photosynthetic rates at warm conditions and presents prompt water use efficiency (WUE) and nitrogen use efficiency (NUE) which are 1.5 to 4 -fold higher than $\mathrm{C}_{3}$ photosynthesis. Challenge to feed the burgeoning global population combined with threats encountered by agricultural crops due to changing climate emphasize on the urgency to exploit the beneficial characteristics of millets. Among millets, foxtail millet (Setaria italica) and its wild progenitor, green foxtail (Setaria viridis) are widely studied since they are considered as models for discerning the traits related to $\mathrm{C}_{4}$ photosynthesis, stress biology and bioenergy traits. In the present scenario of climate change, temperature rise leads to reduction in the yield of millets whereas irregular rainfall adds to this reduction with a negative impact. QTL mapping for different drought tolerance genes in millets will be helpful for breeding climate resilient genotypes. Similarly QTLs for significant general combining ability (GCA) and specific combining ability (SCA) for several yield related traits under stress will also proved to be beneficial for breeding for climate resilience. Stress resistance genes can be incorporated into the genetic background of desired genotypes with marker assisted back crossing and gene pyramiding technique as well as genetic engineering in order to develop climate-resilient crop varieties. 


\section{Introduction}

Farming profitability is unfavorably influenced with genuine effect on production and productivity because of lopsided climate conditions, increased temperature and less accessibility of irrigation water. Worldwide climate change together with the quickly expanding populace is mounting ample amount of pressure on farming area to deliver more nourishment from less land. The foreseen increment in temperature will for the most part influence the hot tropics, mainly populated by developing countries as they are likely to suffer greatest misfortune in agricultural production (Cline, 2007). Indeed, even in temperate locales, a few techniques should be concocted for the adjustment of agrarian yields against unpredictable atmosphere conditions, for example, evolving temperature, arbitrary precipitation, and commencement of extreme floods and dry seasons (Meehl et al., 2007). It has been foreseen that environmental change may seriously affect food production and food security in various drought-prone regions over the globe (FAO, 2005).

This water scarcity is prompting contracting of dietary range and decrease of total food consumption that might provoke hunger issues and nourishment instability (Intergovernmental Panel on Climate Change [IPCC], 2007). A key issue is whether we will have the option to take care of the anticipated worldwide populace of 9 billion in 2050 impartially, strongly and sustainably (Beddington, 2010). Regardless of whether an individual expends enough calories, almost certainly, he may have an inadequate consumption of vital micronutrients, for example, vitamins, minerals and follow components prompting hidden hunger. Pests and diseases are additionally prone to be incredibly affected by changing temperatures.
Development of varieties with appreciable nutraceutical value and improved stress resilience has been one of the priority areas of research nowadays. Current crop improvement systems, for example, genomics-assisted breeding and genetic engineering assume significant job in understanding the complexities of stress reaction and resistance as well as in giving measures to improve productivity. Nonetheless, one of the potential answers for counter these tribulations can be recognizing and improving local yields that are exceptionally versatile to local climate, have high nutritive quality and can proficiently withstand biotic and abiotic stresses. Despite the fact that it is hard to locate a solitary staple nourishment crop that satisfies all the principal criterions, the wide variety and diversity of local food crops, (for example, minor millets) provide us a choice of such climate resilient crops (Shukla et al., 2015).

\section{Millets: A General Introduction}

Most world population relies on cereals as their staple food. Wheat, rice and corn have been the preferred cereals, whereas millets have to a great extent been ignored, more so in the aftermath of green revolution. Millets represent a different gathering of small seeded cultivated grasses developed for food, feed or forage (Lata et al., 2013). They comprise of a dozen crop species that mainly originated in underdeveloped nations, and were domesticated and cultivated by small farmers in semiarid and tropical regions. Peculiar features of the millets are their adaptation to adverse climatic conditions, requirement of minimal inputs, and superior nutritional properties (Lata et al., 2013).

Millets are demanding plant genetic resources for the agriculture that stretches outs food security to deprived ranchers inhabiting dry, barren, marginal and poor lands especially in 
Asia and Africa. The quick maturation and all season growth characteristics make them attractive crops for more intensive cropping systems and they could likewise be used as a catch or relay crop in combination with other crops that are slow in maturation. Regardless of the fact that they are staple in the diets of a great many individuals living in the semi-arid and bone-dry regions of the world, millets are sometimes referred to as "Orphan Crops," or even "Lost Crops." These crops are not really lost but the term indicates their plentitude by the developed countries and also their world production statistics indicate significantly low volumes compared to the other more popular food crops (Belton and Taylor, 2004).

Millets are traditional grains, cultivated and consumed in the Indian subcontinent over 5000 years. Millets are small grained, annual, warm weather cereals belonging to grass family (Poaceae). They are mostly rainfed, hardy grains with a lower requirement of water and fertilizer when compared to other popular cereals and tolerant to drought and other extreme weather conditions. These are one of the few types of coarse grain grasses in the family Poaceae, cultivated for their little consumable seeds. These are generally considered as nutri-cereals as they are rich in carbohydrates, proteins, fats, dietary fibers and minerals. Millets are important crops in the semi-arid tropics of Asia and Africa. The crop is favored due to its productivity and short growing season under high-temperature conditions (Mausch et al., 2017).

Millets are divided into two broad headings: 1) major millets: sorghum and bajra and 2) minor millets: foxtail millet, barnyard millet, kodo millet, little millet, proso millet, finger millet. Millets are nutritionally rich as they contain $7-12 \%$ protein, very less i.e. $2-5 \%$ fat, $65-75 \%$ carbohydrate and $15-20 \%$ dietary fiber. The protein content is comparable to that of wheat and maize. Finger millet contains the lowest fat. One of the important characteristic features of the grain composition in millets is their high ash content. These are also contain iron and phosphorus in a higher proportion. Finger millet has high fiber content and the highest calcium content among all the food grains. Generally, the whole grains are important sources of B complex vitamins, which are mainly concentrated in the outer bran layers of the grain. Sorghum and millets do not contain vitamin $\mathrm{A}$, although certain yellow endosperm varieties contain small amounts of beta-carotene, a precursor of vitamin A. No vitamin $\mathrm{C}$ is present in the raw millet grains.

Millets are having several health benefits. As these are rich source of various nutritional components, thus they possess various beneficial properties such as: 1) slows muscular degradation, 2) reduces the chances of colon cancer, 3) helps to lose weight, 4) treats coronary artery disease, 5) decrease high blood pressure, 6) good source of antioxidants, 7) controls diabetes and 8) aids in sleeping. Despite various health benefits rendered by these small grained grasses, they also contain certain phytochemicals that adversely affect human health by reducing the digestibility of nutrients and mineral absorptions (Sarita and Singh, 2016).

\section{Millet: The best vehicle for fortification}

Fortification may be the cheapest, easiest and best way to combat micro nutrient deficiencies which is the major problem facing in our country like India. Millet being less expensive compared to other cereals and staple food for the downtrodden people could be chosen as the best vehicle for fortification. Micronutrients such as iron, zinc, calcium and vitamins can be used as fortificants in millets. Millets such as finger millet, pearl millet, barnyard millet are some of the millets that are used in various food items. It is also one 
of the most nutritious cereal among the various crops. It is widely grown in most parts of the country. Millets can be incorporated into bakery products as well and it is slowly started using in some of the bakery outlets. And it is nutritious than refined flour. A study has revealed and concluded that finger millet flour can effectively be used as a vehicle for zinc fortification to derive additional amounts of bioaccessible zinc, with reasonably good storage stability, to combat zinc deficiency. Deficiency of zinc is believed to be as widespread as that of iron, with equally serious consequences. Fortification of staple foods with minerals like iron and zinc are one of the cost effective method to combat the micro nutrient deficiencies 7 . Fortification of millet flours with iron might be beneficial in combating iron deficiency. A study has showed that a discoloration was perceived in the dumplings prepared from the same flours where as the overall quality of items like roti prepared was acceptable to the sensory panelists. Finger millet and sorghum flours seem to be suitable as vehicles for fortification with iron.

\section{Climate change}

Climate can be defined as the composite or generally prevailing weather conditions of a region such as temperature, atmospheric pressure, humidity, precipitation, sunshine, cloudiness and wind speed etc. averaged over a series of years. Climate change is any significant long-term change in the expected patterns of average weather of a region.

The climate change in the present scenario is mainly due to the increasing green house gases emission into the atmosphere as a consequence of deforestation, industrialization, urbanization, use of automobiles, use of air conditioners, refrigerators etc. in the modern human lifestyle, burning of fossil fuels and many others. the major green house gases include carbon dioxide, nitrous oxide and chlorofluorocarbons. Human interventions are changing the natural greenhouse on the earth. Burning of fossil fuels like coal and oil has led to increase in the concentration of atmospheric carbon dioxide. Land clearance for agriculture, industry, and other human activities has increased concentrations of greenhouse gases.

\section{The global climate during 2015-19}

Global average temperature has increased by $1.1^{\circ} \mathrm{C}$ since the pre-industrial period, and by $0.2^{\circ} \mathrm{C}$ compared to 2011-2015. World Meteorological Organization (WMO) report on greenhouse gas concentrations shows that 2015-2019 has seen a continued increase in carbon dioxide $\left(\mathrm{CO}_{2}\right)$ levels and other key greenhouse gases in the atmosphere to new records, with $\mathrm{CO}_{2}$ growth rates nearly $20 \%$ higher than the previous five years. Preliminary data from a subset of greenhouse gas observational sites for 2019 indicate that $\mathrm{CO}_{2}$ global concentrations are on track to reach or even exceed $410 \mathrm{ppm}$ by the end of 2019.

The amount of ice lost annually from the Antarctic ice sheet increased at least six-fold, from 40 Gross tonnage (Gt) per year in 19791990 to 252 Gross tonnage (Gt) per year in 2009-2017. Heat waves, which were the deadliest meteorological hazard in the 20152019 period, affecting all continents and resulting in numerous new temperature records. Summer 2019 saw unprecedented wildfires in the Arctic region. In June alone, these fires emitted 50 megatons (Mt) of carbon dioxide into the atmosphere. There were also widespread fires in the nonrenewable tropical rain forests in Southern Asia and Amazon, which have had impacts on the global carbon budget (WMO Report on Global Climate 2015-19). 


\section{Impact of climate change on agriculture}

Problem of irrigation water due to irregular and uneven rainfall. Heavy rainfall leads to flood condition and crop damage due to water stagnation and subsequent anaerobic condition. Waterlogged soil creates problem of soil salinity. Loss of crop biodiversity due to change in climatic condition. Outbreak of insect pest and disease in the crop field causes he economic damage. Evolution of new pathotypes or insect biotypes as a consequence of climate change. Temperature rise hinders effective pollination and fertilization and thus affects seed setting in several crop species. Often weed growth in crop field due to changing climate leads to reduction in crop yield as a result of competition for natural resources. Damage in ozone layer allows UV rays which is harmful for crop plants. UV rays are mutagenic in nature which leads to thymine dimer formation. Green house gases lead to global warming and increased $\mathrm{CO}_{2}$ concentration in the atmosphere resulting in impaired photosynthesis.

\section{Climate resilient agriculture}

The concept of resilience originally comes from engineering and initially referred to solid materials' ability to undergo external stress without breaking or losing functionality. But today, the concept of resilience proliferates in fields as disparate as psychology and information technology. In terms of climate change, resilience means strengthening the ability of living beings to withstand and respond to changes in the earth's climate. Thus the climate resilience has become an important aspect in the agricultural sector in order to stabilize crop yield in the changing climate scenario. There has been a significant rise in the frequency of extreme weather events in recent years affecting farm level productivity and impacting staple food grains availability at the national level. Within a season, severe droughts and floods are being experienced in the same region posing serious problems to the farmers, agricultural scientists and extension staff. Fall in yield leads to shortage of food grains, price rise and inflation affecting the poor most. Therefore, it is of utmost importance to enhance the resilience of agricultural crops to climate change. Both application of improved technologies and new policies will contribute to resilience (Mausch et al., 2017).

\section{Millets: promising crops for the twenty- first century}

Panicoids are a gathering of $\mathrm{C}_{4}$ grasses, which incorporate agronomically significant crops, for example, sorghum and maize, bioenergy feedstocks including sugarcane and miscanthus, nutri-grains, for example, millets, and biofuel crops including switchgrass, napier grass and guinea grass. Among these, millets are known for their atmosphere versatile highlights including adjustment to a wide range of natural conditions, less irrigational prerequisites, better development and profitability in low supplement input conditions, less dependence on chemical fertilizers, and least vulnerability to environmental stresses. (Kole et al., 2015). Millets are also healthfully better than other significant grains like rice and wheat as they are plentiful in dietary strands, starches, vitamins, essential amino acids, stockpiling proteins and other bioactive compounds. These qualities have made millets a crop of choice for cultivation in parched and semi-dry regions of the world; be that as it may, the less endeavor has been made to consider the climate-resilient highlights of millets contrasted with other significant cereals.

In the class of millets, the foxtail millet (Setaria italica) and its wild predecessor, 
green foxtail (S. viridis) are widely investigated since they are considered as model crops for contemplating the qualities identified with $\mathrm{C}_{4}$ photosynthesis, stress science and bioenergy attributes (Muthamilarasan and Prasad, 2015). The accessibility of genome sequence data of these two species has unraveled the abundance of data relating to stress resistance. It has likewise sped up the advancement of large scale genomic assets for crop improvement. To the contrary, investigations on other millets are still in their early stages. The challenge to feed the burgeoning global population with a healthy balanced diet and the dangers experienced by field crops because of changing atmosphere feature the prompt necessity to exploit the helpful characteristics of millets. This could be utilized for the improvement of millets per se as well as other related grass species. The broad gene-level synteny shared between the grass genomes would encourage the transfer and introgression of useful genes, alleles and QTL of agronomic significance recognized in millets to other major cereals.

\section{Why millets?}

Millets are known for their climate-resilient feature including adaptation to a wide range of ecological conditions, less water requirement and less reliance on synthetic fertilizers. Superior to other cereals in fibers, starches, vitamins, essential amino acids as well as other bioactive compounds. Among millets, foxtail millet (Setaria italica) and its progenitor (Setaria viridis) are studied extensively because of traits related to $\mathrm{C}_{4}$, stress biology and bioenergy characteristics. Challenge to feed growing population combined with threats faced by agricultural crops due to changing climate highlight the immediate need to exploit the beneficial attributes of millets (Bandyopadhyay et al., 2017).
Traits responsible for climate-resilience of millets

Millets possess several morpho-physiological, molecular and biochemical traits confer better tolerance to changing climate. Short life-cycle (seed to seed) in millets i.e. 12- 14 weeks than cereals like rice i.e. 20-24 weeks, assists in escaping from stress. Traits responsible for circumventing stress conditions: small leaf area, thickened cell wall, capability to form dense root system. In $\mathrm{C}_{4}$ system, $\mathrm{CO}_{2}$ is concentrated around (Ribulose bisphosphate carboxylase/oxygenase) RuBISCO suppressing RuBP oxygenation and photorespiration.

Thus, $\mathrm{C}_{4}$ mechanism enhances the concentration of $\mathrm{CO}_{2}$ in bundle sheath, which suppresses photorespiration (around 80\%) depending on the temperature and increases the in planta catalytic activity of RuBisCO (Sage et al., 2011). Since RuBISCO works at elevated $\mathrm{CO}_{2}$ levels, millets have enhanced photosynthetic rate at warm climatic conditions and confers higher water and nitrogen use efficiency than $\mathrm{C}_{3}$ plants. In addition to conferring WUE and NUE, $\mathrm{C}_{4}$ photosynthesis provides secondary benefit to millets including improved growth and ecological enactment in warm temperatures, enhanced flexible allocation patterns of biomass and reduced hydraulic conductivity per unit leaf area (Sage and Zhu, 2011).

\section{Genetic and genomic resources available in millets}

Genetic resources serve as primary input for breeding while genomic resources encourage efficient characterization of genetic resources and their subsequent utilization. In the case of millets, ample genetic resources are available however, the information available on genomic resources including molecular markers and physical/genetic maps are scarce 
as compared to major cereals. Availability of genome sequence information of foxtail millet has facilitated the development of several high-throughput genome-wide molecular markers and integrated marker databases.

One such example for utilization of these resources in genomics-assisted breeding (GAB). The scope for improvement of genomic assets for $\mathrm{GAB}$ in foxtail millet is generally higher than other millets attributable to the accessibility of genome sequencing data.

Marker assisted back cross breeding, marker assisted gene pyramiding, genome wide selection, genome editing, and several other tools like next generation sequencing have been suggested for improving stress tolerance in the potential climate resilient millet crops (Bandyopadhyay et al., 2017) (Table 1 and 2).

Table.1 Genes from different millets conferring tolerance to abiotic stresses

\begin{tabular}{|c|c|c|c|}
\hline Millets & Gene & \multirow{2}{*}{$\begin{array}{l}\text { Nature of study } \\
\text { Regulate stress response }\end{array}$} & \multirow{2}{*}{$\begin{array}{l}\text { References } \\
\text { Liu et al., } 2016\end{array}$} \\
\hline \multirow[t]{4}{*}{$\begin{array}{l}\text { Foxtail } \\
\text { millet }\end{array}$} & $\begin{array}{l}\text { Argonaute protein } \\
\text { encoding gene }\end{array}$ & & \\
\hline & WD-40 & $\begin{array}{l}\text { Association with dehydration stress- } \\
\text { responsive pathway }\end{array}$ & $\begin{array}{l}\text { Mishra et } \\
\text { al., } 2012\end{array}$ \\
\hline & $\begin{array}{l}\text { Autophagy-related } \\
\text { gene } \\
\text { (ATG) }\end{array}$ & $\begin{array}{l}\text { Overexpression in Arabidopsis confers } \\
\text { tolerance to nitrogen starvation and drought } \\
\text { stress }\end{array}$ & Li et al., 2015 \\
\hline & $\begin{array}{l}\text { Late embryogenesis } \\
\text { abundant protein } \\
\text { (LEA) }\end{array}$ & $\begin{array}{l}\text { Overexpression of LEA14 in Arabidopsis } \\
\text { and foxtail millet confers tolerance to salt, } \\
\text { osmotic and drought } \\
\text { stress }\end{array}$ & $\begin{array}{l}\text { Wang et } \\
\text { al., } 2014\end{array}$ \\
\hline \multirow[t]{3}{*}{$\begin{array}{l}\text { Finger } \\
\text { millet }\end{array}$} & Dehydrin7 & $\begin{array}{l}\text { Overexpression in tobacco confers } \\
\text { tolerance to drought stress }\end{array}$ & $\begin{array}{l}\text { Singh et } \\
\text { al., } 2015\end{array}$ \\
\hline & $\begin{array}{l}\text { NAC transcription } \\
\text { factor }\end{array}$ & $\begin{array}{l}\text { Overexpression in rice confers tolerance } \\
\text { to salinity and drought stress }\end{array}$ & $\begin{array}{l}\text { Rahman et al., } \\
2016\end{array}$ \\
\hline & $\begin{array}{l}\text { Phosphate transporters } \\
\text { (Pt) }\end{array}$ & $\begin{array}{l}\text { Cloning and characterization of four Pt genes } \\
\text { which showed their involvement } \\
\text { in Pi stress }\end{array}$ & $\begin{array}{l}\text { Pudake et al., } \\
2017\end{array}$ \\
\hline \multirow[t]{3}{*}{$\begin{array}{l}\text { Pearl } \\
\text { millet }\end{array}$} & Glutathione reductase & Involvement pathways in stress-responsive & $\begin{array}{l}\text { Achary et al., } \\
2015\end{array}$ \\
\hline & $\begin{array}{l}\text { Dehydroascorbate } \\
\text { reductase }\end{array}$ & $\begin{array}{l}\text { Involvement in stress-responsive } \\
\text { pathways }\end{array}$ & $\begin{array}{l}\text { Pandey et al., } \\
2014\end{array}$ \\
\hline & $\begin{array}{l}\text { Voltage-dependent } \\
\text { anion channel (VDAC) }\end{array}$ & $\begin{array}{l}\text { Structural and functional characterization } \\
\text { of VDAC along with heterologous over- } \\
\text { expression in yeast which showed } \\
\text { tolerance to several abiotic stresses }\end{array}$ & $\begin{array}{l}\text { Desai et al., } \\
2006\end{array}$ \\
\hline
\end{tabular}


Table.2 Climate Resilient Varieties of Millets from different states in India

\begin{tabular}{|c|c|c|c|}
\hline Crop & Varieties & State & Seed Source \\
\hline \multirow{3}{*}{ Bajra } & GHB-538 and GHB-719 & Gujarat & $\begin{array}{l}\text { Pearl millet Research } \\
\text { Station, JAU, Jamnagar }\end{array}$ \\
\hline & WCC-75 & Karnataka & $\begin{array}{l}\text { GKVK, UAS, } \\
\text { Bangalore/ KSSC/ NSC }\end{array}$ \\
\hline & $\begin{array}{l}\text { RBH-177, RBH-154, } \\
\text { RBH-173 }\end{array}$ & Rajasthan & RSSC, Rajasthan \\
\hline Foxtail Millet & $\begin{array}{l}\text { RS-118, K-211-1, } \\
\text { PS-4, SIA-326 }\end{array}$ & Karnataka & $\begin{array}{l}\text { GKVK, UAS, } \\
\text { Bangalore/ KSSC/ NSC }\end{array}$ \\
\hline \multirow{3}{*}{ Finger Millet } & VR-708,HR-374 & Chhattisgarh & $\begin{array}{l}\text { IGKV / NRC millets, } \\
\text { Bangalore }\end{array}$ \\
\hline & MR-1, MR-6, GPU-66 & Karnataka & $\begin{array}{l}\text { GKVK, UAS, } \\
\text { Bangalore/ KSSC }\end{array}$ \\
\hline & Phule Nachani & Maharashtra & $\begin{array}{l}\text { MPKV, Rahuri; ZARS, } \\
\text { Kolhapur }\end{array}$ \\
\hline \multirow{3}{*}{ Sorghum } & CSH-5, CSH-9, CSV-4 & Karnataka & $\begin{array}{l}\text { GKVK, UAS, } \\
\text { Bangalore/ KSSC }\end{array}$ \\
\hline & Pant Chari 5, Pant Chari 7 & Uttarakhand & GBPUA\&T, Pantnagar \\
\hline & $\begin{array}{l}\text { Phule Chitra, M-35-1 } \\
\text { Phule Vasudha, CSV18 }\end{array}$ & Maharashtra & MPKV, Rahuri \\
\hline
\end{tabular}

Genomics-assisted Breeding in Producing Climate Resilient Crops

Genomics provides tools to focus on the challenge of increasing food yield and quality of production through advanced breeding techniques. Application of DNA markers to facilitate marker-assisted selection (MAS) for crop improvement have proved successful in crossbreeding. Advances in plant genomics offer means to boost the understandings of crop diversity at genetic levels and stimulate the rate of genetic improvement (Muthamilarasan et al., 2013). Breeding strategy driven by genomic studies are helpful for the development of new cultivars that are "climate change ready" (Varshney et al., 2005). Information obtained from multienvironment testing provide an opportunity for modeling "stress-impacts" on crops. Plant breeders and gene bank curators will scan for the morphological and physiological traits in accessible germplasm that could improve crop adaptation under such climate variability. Plant breeders should search for the several morphological and physiological traits in the available germplasm.

Genetic mapping and QTL analysis by dint of bi-parental or association mapping (AM) populations, have stimulated the dissection of complex genetic loci which control several traits, potentially allowing MAS, QTL and AM studies or direct calculation and genomic selection (GS) of high value genotypes beneficial to breeding programmes (Kulwal et al., 2011). Advancement of next-generation sequencing (NGS) methods has facilitated the development of large numbers of genetic markers, such as single nucleotide polymorphisms (SNP), insertion-deletions (InDels), etc. even in relatively researchneglected potential crop species such as millets. Discovery of novel genes/alleles for any given trait could be then performed through genotyping-by-sequencing (GBS) 
approaches. Likewise, genome-wide association studies (GWAS) could be used to identify the genomic regions governing traits of interest by implementing statistical associations between DNA polymorphisms and trait variations in varied collection of germplasms that are genotyped and phenotyped for traits of interest. NGS coupled with GWAS enhances the mapping resolution for precise location of genes/alleles/QTL (Ma et al., 2012; Liu et al., 2013 and Varshney et al., 2014).

\section{Application of genomics-assisted breeding for generation of climate resilient millets}

These nutri-cereals or millets are well known for their climate-resilient features including adaptation to a wide range of ecological conditions, less water demand and less reliance on synthetic fertilizers. Among all the millets cultivated across the globe, foxtail millet is considered as the model crop to study the biology of other millets and biofuel crops (Lata et al., 2013 and Muthamilarasan and Prasad, 2015). As foxtail millet serves as a rich source of genes or QTL for genetic improvement of major cereals and bioenergy grasses, large-scale genomic resources were developed including simple sequence repeats (SSRs) (Pandey et al., 2013 and Zhang et al., 2014), intron length polymorphisms (Muthamilarasan et al., 2014), eSSRs (Kumari et al., 2013), miRNA-based markers (Yadav et al., 2014) and transposableelements based markers (Yadav et al., 2015).

Furthermore, open access online databases such as foxtail millet marker database (FmMDb) (Suresh et al., 2013), foxtail millet miRNA database (FmMiRNADb) (Khan et al., 2014) and foxtail millet transposable elements-based marker database (FmTEMDb) (Yadav et al., 2015) have been created. Along with the development of these markers, their applicability in population genetics, association mapping, comparative genomics study and genomics-assisted breeding have also been demonstrated (Muthamilarasan and Prasad, 2015). An allele-specific marker developed from an SNP in SiDREB2 gene linked to drought tolerance in foxtail millet (Lata et al., 2011) is being used in allele mining and MAS for drought tolerance (Lata and Prasad, 2013).

Three major QTL for grain yield with low QTL $\times$ environment interactions were identified in bajra across a range of postflowering moisture environments (Bidinger $e t$ al., 2007). One of these major QTLs accounted for up to $32 \%$ of the phenotypic variance of grain yield under drought which was validated in two independent MABC programs in which $30 \%$ improvement in general combining ability for grain yield was expected (Yadav et al., 2011).

The genetic potential of finger millet serves as an indispensable resource for understanding the genomics of abiotic stress tolerance (Kumar et al., 2015). Genomic approaches like structural, functional and comparative genomic can be utilized, to determine the special attributes found in finger millets and endeavor them for crop improvement purposes. Functional genomics has led to the identification of several nutritionally important genes including those encoding calcium transporters and seed storage proteins. De novo RNA sequencing technology has been used to sequence the finger millet grain-filling stages transcriptome (Kumar et al., 2015). Comparison of the genomes across species can reveal the similarities and differences in genome structure and organization (comparative genomics). Such studies can reveal the evolutionary relationship between species and may be useful in predicting key genes playing role in abiotic stress tolerance. Indeed, extensive similarities have been known to be 
shared across plant genomes of even distantly related species (Guyot et al., 2012).

Contrasted with other crops, research on millets is at preliminary stage. Being predominantly climate resilient crops, millets could serve as important source of novel genes and QTL for stress tolerance, which needs to be identified and characterized. The close phylogenetic relationships between millets and other cereals could facilitate the introgression of novel alleles, genes or QTL identified in millets into other cereals toward ensuring food security under changing climate.

In conclusions, it is realized that millets hold great promise for food security and nutrition amid ever- increasing agricultural costs, climate change and burgeoning mouths to feed worldwide. They are nutritious, possess additional health benefits, requires significantly fewer input costs for cultivation. These features accentuate millets as crops of choice for the world population amid growing concerns about climate change. Rise in temperature in the present scenario leads to reduction in the yield of millets whereas amount of rainfall adds to this reduction with a negative impact. Thus there arises a need for climate resilient millet breeding with suitable millet model for simulation and preparing crop plan according to that. QTL mapping for different drought tolerance genes in millets will be helpful for breeding climate resilient genotypes. Stress resistance genes can be introgressed into the genetic background of desired genotypes with marker assisted back crossing and gene pyramiding technique.

\section{References}

Achary, V. M. M., Reddy, C. S., Pandey, P., Islam, T., Kaul, T. and Reddy, M. K. (2015). Glutathione reductase a unique enzyme: molecular cloning, expression and biochemical characterization from the stress adapted C 4 plant, Pennisetum glaucum (L.) R. Br. Molecular Biology Reports, 42(5), 947-962.

Bandyopadhyay, T., Muthamilarasan, M. and Prasad, M. (2017). Millets for next generation climate-smart agriculture. Frontiers in plant science, 8, 1266.

Beddington, J. (2010). Food security: contributions from science to a new and greener revolution. Philosophical Transactions of the Royal Society B: Biological Sciences, 365(1537), 61-71.

Belton, P. S. and Taylor, J. R. (2004). Sorghum and millets: protein sources for Africa. Trends in Food Science \& Technology, 15(2), 94-98.

Bidinger, F. R., Nepolean, T., Hash, C. T., Yadav, R. S. and Howarth, C. J. (2007). Quantitative trait loci for grain yield in pearl millet under variable post flowering moisture conditions. Crop science, 47(3), 969980.

Cline, W. R. (2007). Global warming and agriculture: Impact estimates by country. Peterson Institute.

Desai, M. K., Mishra, R. N., Verma, D., Nair, S., Sopory, S. K. and Reddy, M. K. (2006). Structural and functional analysis of a salt stress inducible gene encoding voltage dependent anion channel (VDAC) from pearl millet (Pennisetum glaucum). Plant Physiology and Biochemistry, 44(7-9), 483-493.

Guyot, R., Lefebvre-Pautigny, F., TranchantDubreuil, C., Rigoreau, M., Hamon, P., Leroy, T. and De Kochko, A. (2012). Ancestral synteny shared between distantly-related plant species from the asterid (Coffea canephora and Solanum sp.) and rosid (Vitis vinifera) clades. BMC genomics, 13(1), 
1-14.

Khan, Y., Yadav, A., Bonthala, V. S., Muthamilarasan, M., Yadav, C. B. and Prasad, M. (2014). Comprehensive genome-wide identification and expression profiling of foxtail millet [Setaria italica (L.)] miRNAs in response to abiotic stress and development of miRNA database. Plant Cell, Tissue and Organ Culture (PCTOC), 118(2), 279-292.

Kole, C., Muthamilarasan, M., Henry, R., Edwards, D., Sharma, R., Abberton, M. and Cai, H. (2015). Application of genomics-assisted breeding for generation of climate resilient crops: progress and prospects. Frontiers in plant science, 6, 563.

Kulwal, P., Thudi, M. and Varshney, R. K. (2011). Genomics interventions in crop breeding for sustainable agriculture.

Kumar, A., Gaur, V. S., Goel, A. and Gupta, A. K. (2015). De novo assembly and characterization of developing spikes transcriptome of finger millet (Eleusine coracana): a minor crop having nutraceutical properties. Plant molecular biology reporter,33(4), 905-922.

Kumar, A., Pathak, R. K., Gupta, S. M., Gaur, V. S. and Pandey, D. (2015). Systems biology for smart crops and agricultural innovation: filling the gaps between genotype and phenotype for complex traits linked with robust agricultural productivity and sustainability. Omics: a journal of integrative biology, 19(10), 581-601.

Kumari, K., Muthamilarasan, M., Misra, G., Gupta, S., Subramanian, A., Parida, S. K. and Prasad, M. (2013). Development of eSSR-markers in Setaria italica and their applicability in studying genetic diversity, crosstransferability and comparative mapping in millet and non-millet species. PloS one, 8(6), e67742.

Lata, C. and Prasad, M. (2013). Validation of an allele-specific marker associated with dehydration stress tolerance in a core set of foxtail millet accessions. Plant Breeding, 132(5), 496-499.

Lata, C. and Prasad, M. (2014). Association of an allele-specific marker with dehydration stress tolerance in foxtail millet suggests SiDREB2 to be an important QTL. Journal of plant biochemistry and biotechnology, 23(1), 119-122.

Lata, C., Bhutty, S., Bahadur, R. P., Majee, M. and Prasad, M. (2011). Association of an SNP in a novel DREB2-like gene SiDREB2 with stress tolerance in foxtail millet [Setaria italica (L.)]. Journal of experimental botany, 62(10), 3387-3401.

Lata, C., Gupta, S. and Prasad, M. (2013). Foxtail millet: a model crop for genetic and genomic studies in bioenergy grasses. Critical reviews in biotechnology, 33(3), 328-343.

Li, W. W., Chen, M., Zhong, L., Liu, J. M., Xu, Z. S., Li, L. C., and Ma, Y. Z. (2015). Overexpression of the autophagy-related gene SiATG8a from foxtail millet (Setaria italica L.) confers tolerance to both nitrogen starvation and drought stress in Arabidopsis. Biochemical and biophysical research communications, 468(4), 800-806.

Liu, S., Wang, X., Wang, H., Xin, H., Yang, X., Yan, J. and Qin, F. (2013). Genome-wide analysis of ZmDREB genes and their association with natural variation in drought tolerance at seedling stage of Zea mays L. PLoS Genet, 9(9), e1003790.

Liu, X., Tang, S., Jia, G., Schnable, J. C., Su, H., Tang, C. and Diao, X. (2016). The C-terminal motif of SiAGO1b is 
required for the regulation of growth, development and stress responses in foxtail millet (Setaria italica (L.) P. Beauv). Journal of experimental botany, 67(11), 3237-3249.

Ma, Y., Qin, F. and Tran, L. S. P. (2012). Contribution of genomics to gene discovery in plant abiotic stress responses. Molecular plant, 5(6), 1176-1178.

Mausch, K., Orr, A. and Miller, B. P. (2017). Targeting resilience and profitability in African smallholder agriculture: Insights from ICRISAT-led research programs.

Meehl, G. A., Stocker, T. F., Collins, W. D., Friedlingstein, P., Gaye, T., Gregory, J. M. and Raper, S. C. (2007). Global climate projections.

Mishra, A. K., Puranik, S., Bahadur, R. P. and Prasad, M. (2012). The DNA-binding activity of an AP2 protein is involved in transcriptional regulation of a stressresponsive gene, SiWD40, in foxtail millet. Genomics, 100(4), 252-263.

Muthamilarasan, M. and Prasad, M. (2015). Advances in Setaria genomics for genetic improvement of cereals and bioenergy grasses. Theoretical and applied genetics, 128(1), 1-14.

Muthamilarasan, M., Misra, G. and Prasad, M. (2013). FmMDb: a versatile database of foxtail millet markers for millets and bioenergy grasses research. PloS one, 8(8), e71418.

Muthamilarasan, M., Theriappan, P. and Prasad, M. (2013). Recent advances in crop genomics for ensuring food security. Current Science, 105(2), 155158 .

Muthamilarasan, M., Venkata Suresh, B., Pandey, G., Kumari, K., Parida, S. K. and Prasad, M. (2014). Development of 5123 intron-length polymorphic markers for large-scale genotyping applications in foxtail millet. DNA research, 21(1), 41-52.

Pandey, G., Misra, G., Kumari, K., Gupta, S., Parida, S. K., Chattopadhyay, D. and Prasad, M. (2013). Genome-wide development and use of microsatellite markers for large-scale genotyping applications in foxtail millet [Setaria italica (L.)]. DNA research,20(2), 197-207.

Pandey, P., Achary, V. M. M., Kalasamudramu, V., Mahanty, S., Reddy, G. M. and Reddy, M. K. (2014). Molecular and biochemical characterization of dehydroascorbate reductase from a stress adapted $\mathrm{C} 4$ plant, pearl millet [Pennisetum glaucum (L.) R. Br]. Plant cell reports, 33(3), 435-445.

Pudake, R. N., Mehta, C. M., Mohanta, T. K., Sharma, S., Varma, A. and Sharma, A. K. (2017). Expression of four phosphate transporter genes from Finger millet (Eleusine coracana L.) in response to mycorrhizal colonization and Pi stress. 3 Biotech, 7(1), 17.

Rahman, H., Ramanathan, V., Nallathambi, J., Duraialagaraja, S. and Muthurajan, R. (2016). Over-expression of a NAC 67 transcription factor from finger millet (Eleusine coracana L.) confers tolerance against salinity and drought stress in rice. $B M C$ biotechnology, 16(1), 35.

Sage, R. F. and Zhu, X. G. (2011). Exploiting the engine of $\mathrm{C} 4$ photosynthesis. Journal of experimental botany,62(9), 29893000.

Sarita, E. S. and Singh, E. (2016). Potential of millets: nutrients composition and health benefits. Journal of Scientific and Innovative Research, 5(2), 46-50.

Shukla, A., Lalit, A., Sharma, V., Vats, S. and Alam, A. (2015). Pearl and finger millets: the hope of food security. Applied Research 
Journal, 1(2), 59-66.

Singh, R. K., Singh, V. K., Raghavendrarao, S., Phanindra, M. L. V., Raman, K. V., Solanke, A. U. and Sharma, T. R. (2015). Expression of finger millet EcDehydrin7 in transgenic tobacco confers tolerance to drought stress. Applied biochemistry and biotechnology, 177(1), 207-216.

Varshney, R. K., Graner, A. and Sorrells, M. E. (2005). Genomics-assisted breeding for crop improvement. Trends in plant science, 10(12), 621-630.

Varshney, R. K., Terauchi, R. and McCouch, S. R. (2014). Harvesting the promising fruits of genomics: applying genome sequencing technologies to crop breeding. PLoS Biol, 12(6), e1001883.

Wang, M., Li, P., Li, C., Pan, Y., Jiang, X., Zhu, D. and Yu, J. (2014). SiLEA14, a novel atypical LEA protein, confers abiotic stress resistance in foxtail millet. BMC plant biology, 14(1), 290.

Yadav, C. B., Bonthala, V. S., Muthamilarasan, M., Pandey, G., Khan, Y. and Prasad, M. (2015). Genome-wide development of transposable elements-based markers in foxtail millet and construction of an integrated database. DNA research, 22(1), 79-90.

Yadav, C. B., Muthamilarasan, M., Pandey, G., Khan, Y. and Prasad, M. (2014). Development of novel microRNAbased genetic markers in foxtail millet for genotyping applications in related grass species. Molecular breeding, 34(4), 2219-2224.

Yadav, R. S., Sehgal, D. and Vadez, V. (2011). Using genetic mapping and genomics approaches in understanding and improving drought tolerance in pearl millet. Journal of Experimental Botany, 62(2), 397-408.

Zhang, S., Tang, C., Zhao, Q., Li, J., Yang, L., Qie, L. and Liu, X. (2014). Development of highly polymorphic simple sequence repeat markers using genome-wide microsatellite variant analysis in Foxtail millet [Setaria italica (L.) P. Beauv.]. BMC genomics, 15(1), 78.

\section{How to cite this article:}

Biswajit Lenka, G. U. Kulkarni, Ankit Moharana, Aditya Pratap Singh, Gouri Shankar Pradhan and Lakesh Muduli. 2020. Millets: Promising Crops for Climate-Smart Agriculture. Int.J.Curr.Microbiol.App.Sci. 9(11): 656-668. doi: https://doi.org/10.20546/ijcmas.2020.911.081 